\title{
Caring for Sexual and Gender Minority Patients: What Factors Explain Self-Reported Competence among Health Care Professional Students?
}

\author{
Mandi L. Pratt-Chapman ( $\square$ mandi@gwu.edu ) \\ George Washington University https://orcid.org/0000-0002-9303-7659 \\ Jennifer Potter \\ Harvard Medical School
}

\section{Research article}

Keywords: Health care professional students, cultural competence, LGBTQ knowledge, LGBTQ attitudes, LGBTQ beliefs, LGBTQ clinical preparedness

Posted Date: October 7th, 2020

DOI: https://doi.org/10.21203/rs.3.rs-83272/v1

License: (1) (1) This work is licensed under a Creative Commons Attribution 4.0 International License. Read Full License 


\section{Abstract}

Background: Lesbian, gay, bisexual, transgender, queer and intersex people comprise approximately $5 \%$ of the U.S. population, yet health care professional student education on sexual and gender minority (SGM) health is sparse. This study explored the degree to which sociodemographic factors and student affiliation with SGM people explained self-reported competence in caring for SGM patients.

Methods: Multiple linear regression was used to test the value of an eight-variable exploratory (Full Model) for each of five criterion variables. Independent variables that explained a meaningful amount $(\geq 0.15)$ of total variance were retained in Reduced Models for parsimony. The criterion variables were: Basic Knowledge, Attitudinal Awareness and Clinical Preparedness (subscales of the Lesbian, Gay, Bisexual, Transgender Development of Clinical Skills Scale); and Beliefs and Behaviors (subscales of the Gay Affirming Practice Scale).

Results: Political affiliation, religiosity, and SGM affiliation were predictor variables in half of the Reduced Models. SGM-specific health training hours were included in Reduced Models for Clinical Preparedness and affirming Behaviors.

Conclusion: Sociodemographic factors, lived experiences, and amount of training in SGM-specific health matter when it comes to health care professional students' sense of preparedness in caring for SGM patients.

\section{Introduction}

Lesbian, gay, bisexual, transgender, queer and intersex people comprise approximately $5 \%$ of the U.S. population, ${ }^{1-3}$ yet healthcare professional student education on sexual and gender minority (SGM) health topics is sparse. ${ }^{4-8}$ Past studies have suggested that more SGM-specific health training, ${ }^{5,9,10}$ personal and professional experiences with SGM people, ${ }^{11-14}$ and certain sociodemographic factors are associated with increased clinician competence in caring for SGM patients. ${ }^{15-16}$ Specifically, identifying as lesbian, gay, bisexual, transgender, or queer (LGBTQ); female sex-assigned-at-birth; ; ${ }^{17-26}$ liberal political affiliation; $21,22,27$ less religiosity; $9,14,22,28$ and less spirituality ${ }^{29}$ have predicted more affirming attitudes toward SGM people. Also, younger age, ${ }^{10}$ white (versus non-white) race, ${ }^{18,20,26}$ and less conservative religion, ${ }^{9,21,30}$ have predicted less bias toward SGM people in past samples. Other variables that have been associated with greater SGM bias include belief in traditional gender roles, ${ }^{21,31}$ acceptance of male aggressiveness, ${ }^{31}$ racist attitudes, ${ }^{21}$ lack of egalitarian humanism, ${ }^{21}$ rural residence, ${ }^{21}$ and lower educational attainment. ${ }^{21}$ Association of professional identity with attitudes toward SGM people has not been well studied. ${ }^{26,32}$

This study builds on prior research in the literature that explores the association of sociodemographic factors with health care professional student self-reported knowledge, attitudes, clinical preparedness, beliefs, and behaviors in caring for SGM patients. Starting with an exploratory model that includes eight independent variables (Full Model), this study sought to define parsimonious Reduced Models that explained a meaningful $(\geq 0.15)$ amount of total variance across a sample of health care professional students in terms of five criterion variables that measure constructs related to cultural competence in caring for SGM patients.

\section{Methods}

Participants

The sample for this study was a subset of health care professional students and faculty previously surveyed for another purpose. ${ }^{33}$ The primary study examined the effectiveness of an elective symposium on LGBTQI health on the knowledge, attitudes, clinical preparedness, beliefs and behaviors of health care professional students at an urban university. ${ }^{33}$ The present sample was limited to students in the control group of the primary study who answered all eight independent variables being tested $(n=48)$.

Participant characteristics are shown in Table 1. The sample was primarily white (65\%), female (68.8\%), and heterosexual (66.7\%). The majority of students were medical students in clinical years of training (52.1\%). Approximately $90 \%$ of participants reported being mostly or very liberal. Overall, the sample was more spiritual than religious and represented a variety of religions.

Ethical Review 
The George Washington University IRB determined this study to be exempt (\#180645) under Department of Health and Human Services regulatory categories 2 and 4 .

Measures

The online survey asked a total of 144 questions, 61 of which were included in this study. Items included 13 demographic and experience questions, the Lesbian, Gay, Bisexual, Transgender Development of Clinical Skills Scale (LGBT-DOCSS), ${ }^{14}$ and the Gay Affirming Practice Scale (GAPS). ${ }^{34}$

LGBT-DOCSS ${ }^{14}$

The LGBT-DOCSS is an 18-item scale with three subscales that measure constructs associated with self-reported competence in caring for SGM patients across interdisciplinary health care professionals. The scale has been tested for factor structure, reliability, and validity. ${ }^{14}$ In the original instrument, respondents rated their agreement with each item on a 7-point scale from strongly disagree (1) to strongly agree (7) for a total score ranging from 18-126 for the overall scale. Subscale ranges are: Basic Knowledge (4-28), Attitudinal Awareness (7-49); Clinical Preparedness (7-49). Total scores for the full scale and each subscale are intended to be tallied and then divided by the total number of items to obtain a mean score. Higher scores reflect greater self-reported competence in each domain.

In this study, the LGBT-DOCSS was altered by reducing response options from a 7-point to a 5-point scale and reversing directionality of the scale to ensure cognitive consistency of the directionality and range of response categories for all items of the survey. As recommended by Dillman, to provide a more authentic non-response option while retaining reasonable estimates of respondent attitudes, the middle answer option was moved to the far right to distinguish it as "Not sure" rather than neutral. ${ }^{35,36}$ One item in the factor analysis of the LGBT-DOCSS manuscript was different from the final instrument published; ${ }^{14}$ therefore, both items were included. After correspondence with the scale author (M. Pratt-Chapman to M. Bidell, October 2018); however, only the valid, confirmed item was used in this analysis. Subscales were tallied for composite scores with a range of 4-20 (Knowledge), 7-35 (Attitudes), and 7-35 (Clinical Preparedness). Higher scores reflect greater knowledge, more affirming attitudes, and greater clinical preparedness, respectively.

GAPS $^{34}$

The GAPS is a 30-item scale designed to measure health practitioners' beliefs and behaviors regarding care of gay and lesbian individuals. The instrument uses a 5-point Likert scale from strongly agree (5) to strongly disagree (1) for items 1-15 and from always (5) to never (1) for items 16-30. The directionality and scoring for items were retained from the original instrument with the neutral answer option shifted to the far right to allow for a genuine non-response option as with the prior two scales. The range of possible scores for each subscale is $15-75$ with a higher score reflecting more affirming Beliefs or Behaviors, respectively. Crisp established construct validity and strong internal reliability for each subscale.

Statistical Analysis

Data were accessed through the secure RedCap database and analyzed using SPSS 24 (Armonk, NY). Since answers to the independent variables being tested were criteria for inclusion in the study, independent variables had no missing data but resulted in a limited sample size. Data for independent variables were not imputed due to the personal nature of sex-assigned-at-birth, sexual orientation, religiosity, spirituality, and political affiliation-characteristics that are inherent to the nature of the respondent. Missing data for dependent variables was less than $5 \%$. Based on Cheema, ${ }^{37}$ this low amount of missing data can be dealt with in numerous ways, including multiple imputation techniques or leaving data as missing. For this study, data were left as missing.

G*Power 3.1.8.2 (Faul, Erdfelder, Buchner, \& Lang, 2009) was used to conduct posthoc power analyses for all models, individual predictor variables within models, and model comparisons. Based on the posthoc power analyses, the secondary sample was underpowered $(1-\beta<.80)$ for most models to explain a medium effect $\left(f^{2}=.13\right)$ for $a=.05$ and for most individual predictors to detect a small effect $\left(f^{2}=.02\right)$ for $a=.05 .^{38}$ For Reduced Models, power ranged from $(1-\beta)=.36-.75$ with all Reduced Models powered at $(1-\beta)$ $\geq .50$. Because the sample was underpowered, variance in the criterion variable explained by individual predictors and for each model were examined rather than statistical significance. ${ }^{38}$ 
Multiple linear regression was used to test the value of an eight-variable model (Full Model) for each criterion variable. The eight independent variables were: sexual orientation, sex-assigned-at-birth, political affiliation, religiosity, spirituality, SGM affiliation (identifying as or having a friend or family member who identifies as LGBTQ), number of SGM-specific training hours, and number of SGM patient interactions in the last six months. Statistical significance of independent variables within each model as well as percent of variance explained was examined. Using Cohen's ${ }^{38}$ benchmarks for a small proportion of variance explained, any variable explaining $>2 \%$ unique variance was included in the Reduced Model. Reduced Models were examined for statistical significance and proportion of variance explained based on Cohen's ${ }^{38}$ benchmarks: small $\left(R^{2}=.02\right)$, medium $\left(R^{2}=.13\right)$, and large $\left(R^{2}=.26\right)$. For all Reduced Models, interaction effects were examined by creating cross-product terms. ${ }^{39}$ Selection of final variables was based on model comparisons. $^{39,40}$ Tolerance and VIF were checked for all Reduced Models to ensure that collinearity did not apply. Correlations of all independent variables and each criterion variable were also examined.

Descriptive and inferential statistics were reported. Ordinary Least Squares was used to test individual predictor variables. Multiple $R$ was reported for correlation between the criterion variable and all predictors in each model. Multiple $R^{2}$ was reported for percent variance in each criterion variable explained by all predictors in each model. Reduced Models were considered meaningful and parsimonious if there was no more than a 10\% drop in total variance from the Full to the Reduced Model.

\section{Results}

Reduced Models explained a statistically significant amount of variance for Basic Knowledge and Attitudinal Awareness subscales of the LGBT-DOCSS and for the Beliefs and Behaviors subscales of the GAPS $(p \leq 0.05)$. The Reduced Model for the Clinical Preparedness subscale of the LGBT-DOCSS did not explain a statistically significant amount of variance.

Political affiliation, religiosity, and SGM affiliation were predictor variables in half of the Reduced Models (see Tables 2-6). Less religiosity, greater SGM affiliation, and greater number of SGM patients explained greater self-reported Basic Knowledge of SGM health (LGBT-DOCSS). Political affiliation was the only meaningful predictor of self-reported SGM-affirming attitudes as measured by the Attitudinal Awareness subscale LGBT-DOCSS. Together religiosity, spirituality, and number of SGM-specific health training hours explained a statistically insignificant, but meaningful amount of variance for self-reported Clinical Preparedness in caring for SGM patients (LGBT-DOCSS). Political affiliation and SGM affiliation together explained nearly half of the variance in self-reported beliefs about how providers should care for SGM patients as measured by the GAPS-Beliefs subscale. Together, sexual orientation, political affiliation, spirituality, and number of SGM training hours explained slightly more than half of variance in the sample as measured by the GAPS-Behavior subscale.

\section{Discussion}

Five of the five Reduced Models explained a statistically significant amount of total variance for their respective criterion variables. This means that sociodemographic factors, lived experiences, and amount of training in SGM-specific health matter a great deal when it comes to health care professional students' overall sense of competence in caring for SGM patients.

Political affiliation-only one independent variable-explained nearly half of the total sample variance in self-reported attitudes about SGM patients based on one subscale (Attitudinal Awareness, LGBT-DOCSS) and was included in half of the Reduced Models. It is important to note that the political affiliation variable was dichotomized to "liberal" versus "not liberal" by combining conservative, very conservative, neither liberal nor conservative, and apolitical into the "not liberal" category due to small sample sizes for each level. The significance of political affiliation in explaining variance in criterion variables tested in this study is striking.

The association of political affiliation with health care professional student attitudes in this study is a challenging finding. Health care professional schools cannot and should not make acceptance into health care professional training subject to political affiliation. However, negative attitudes toward SGM patients should not be tolerated. This finding suggests that solutions are needed to bridge polarized social attitudes when it comes to patient care. Health care is a helping profession with a guiding value to "do no harm." While social and political attitudes may vary widely among health care professionals and students, the principles of patient autonomy, medical and research beneficence, and justice can serve as an ethical framework for bridging sociopolitical divides in order to optimize the health and wellness of patients from diverse lived experiences. Future studies that examine ways to bridge political and social differences through exploration of shared professional values are needed. 
The fact that association with friends and family who identify as LGBTQ explained greater self-reported knowledge and more affirming attitudes and beliefs toward SGM patients suggests a possible way forward for future education and training. Specifically, educational interventions should consider student dialogue with SGM community members, faculty, and peers as one way to increase student's sense of knowledge and to foster more affirming attitudes and beliefs about their SGM patients.

The association of strong spirituality with more affirming clinical preparedness and behaviors is a novel finding and contrary to past research. ${ }^{33}$ In fact, this is the first known study to report the association of strong spirituality with greater self-reported clinical preparedness and more affirming clinical behaviors for SGM patients. It is important to interpret this finding with caution for several reasons: First, there was an interaction between spirituality and number of training hours on self-reported clinical behaviors. Second, definitions of spirituality vary, making it a complex construct to interpret. Third, social desirability bias may have played a role in selfreport scores. It is important to note that greater spirituality did not equate to greater religiosity or vice versa: These variables were negatively associated. Further exploration of the relationship between health care providers' spirituality and attitudes toward SGM people is warranted.

There were several key limitations in this study: limitations of one of the instruments, the small sample size, and the non-representative nature of the sample.

Another limitation of this study is the small, convenience sample derived from one academic institution, ${ }^{33}$ limiting generalizability. The voluntary, opt-in recruitment approach may have resulted in respondents who were more likely to be interested in SGM health generally. Furthermore, the study was cross-sectional; therefore, results are only a snapshot in time and may not represent evolving studentreported knowledge, attitudes, clinical preparedness, beliefs, and behaviors over time. This sample also lacks representativeness in that it was overwhelmingly liberal. Future studies should consider oversampling conservative, male, non-white, and non-Christian health care professional students to allow for subgroup analyses of political affiliation, sex-assigned-at-birth, race, and religion. However, while the sample size was small, findings were statistically significant-which means results are actually stronger than in a larger (powered) sample. ${ }^{41}$ So while the findings cannot be assumed generalizable, the findings should be interpreted as valid for the sample studied.

Finally, it is important to emphasize the exploratory nature of the study. While constructs were drawn from the literature, there was little prior research on which to test predetermined models for their predictive value.

\section{Conclusions}

Additional research studies in diverse settings with diverse samples are needed to confirm results reported from this study. Researchers can build on the present study by improving the psychometric rigor and availability of scales that measure health professional student clinical preparedness and behaviors. As theory and research on SGM clinical preparedness grows, confirmatory studies using more sophisticated modeling techniques-such as hierarchical modeling of theory-driven variables and mixed effects models are warranted. Additional approaches to measure implicit bias and longitudinal clinical practices of student learners are also needed. Ultimately, the field will benefit from assessing clinical competence through objective instruments, not simply self-reported measures. In tandem, innovative educational approaches are needed to ensure that affirming care is provided to SGM patients regardless of the sociopolitical background of the provider.

\section{Abbreviations}

GAPS: Gay Affirming Practice Scale

LGBT-DOCSS: The lesbian, gay, bisexual, and transgender development of clinical skills scale

LGBTQI: Lesbian, gay, bisexual, transgender, queer, and intersex

SGM: Sexual and gender minority

\section{Declarations}

\section{Ethics approval and consent to participate}


This study was determined to be exempt from full IRB review by the George Washington University IRB (\#180842). This study was a secondary analysis of data collected for another purpose.

\section{Consent for publication}

Not applicable.

\section{Availability of data and materials}

Data is available upon request to the corresponding author.

\section{Competing interests}

The authors declare no competing interests

\section{Funding}

No funding was provided for this study.

\section{Authors' contributions}

MPC conceptualized the study, collected and analyzed data, wrote the manuscript, and approved the final submission. JP reviewed the manuscript, provided feedback, and approved the final version.

\section{Acknowledgements}

The authors would like to acknowledge the following individuals who served on the corresponding author's dissertation committee: Leslie Davidson, PhD, Chair of the Department of Clinical Research and Leadership at the George Washington University School of Medicine and Health Sciences served as Chair of her dissertation committee. Brandi A Weiss, PhD guided the quantitative methods. Thank you also to dissertation readers Markus Bidell, PhD and Lawrence Deyton, MD.

\section{References}

1. Gates GJ: How many people are lesbian, gay, bisexual and transgender? The Williams Institute. 2011.

2. Flores AR, Herman JL, Gates GJ, Brown TNT: How many adults identify as transgender in the United States? The Williams Institute. 2016.

3. IC4E. How common is intersex? An explanation of the stats. Available at: intersexequality.com/how-common-is-intersex-inhumans/. Accessed March 30, 2020.

4. Obedin-Maliver J, Goldsmith ES, Stewart L, et al: Lesbian, gay, bisexual, and transgender-related content in undergraduate medical education. JAMA 2011;306(9):971-977.

5. Dowshen N, Gilbert K, Feiler A, Lee S: Transgender health education impact on medical student knowledge, skills and attitudes. $J$ Adolesc Health 2013;52(2):S235.

6. Burke SE, Dovidio JF, Przedworski JM et al: Do contact and empathy mitigate bias against gay and lesbian people among heterosexual medical students? A report from medical student CHANGES. Acad Med 2015;90:645-651.

7. Braun HM, Ramirez D, Zahner GJ, et al: The LGBTQI health forum: an innovative interprofessional initiative to support curriculum reform. Med Educ Online 2017;22(1):1306419.

8. Lim FA, Johnson M, Eliason M: A national survey of faculty knowledge, experience, and readiness for teaching lesbian, gay, bisexual and transgender health in baccalaureate nursing program. Nurs Educ Perspect 2015;36(4):144-152.

9. Cramer E: Effects of an educational unit about lesbian identity development and disclosure in a social work methods course. $J$ Soc Work Educ 1997;33:467-79.

10. Bidell MP: Addressing disparities: The impact of a lesbian, gay, bisexual, and transgender graduate counselling course. Couns Psychother Res 2013;13(4): 300-307.

11. Phelan SM, Burke SE, Hardeman RR, et al: Medical school factors associated with changes in implicit and explicit bias against gay and lesbian people among 3492 graduating medical students. J Gen Intern Med 2017;32(11):1193-201. 
12. Earnshaw VA, Jin H, Wickersham JA, et al: Stigma toward men who have sex with men among future healthcare providers in Malaysia: Would more interpersonal contact reduce prejudice? AIDS Behav 2016;20(1):98-106.

13. Tucker A, Lih J, de Swardt G, et al: Efficacy of tailored clinic trainings to improve knowledge of men who have sex with men health needs and reduce homoprejudicial attitudes in South Africa. LGBT Health 2016;(6):443-50.

14. Bidell MP: The lesbian, gay, bisexual, and transgender development of clinical skills scale (LGBT-DOCSS): Establishing a new interdisciplinary self-assessment for health providers. J Homosex 2017;64(10):1432-60.

15. McKelvey RS, Webb JA, Baldassar LV, Robinson SM, Riley G: Sex knowledge and sexual attitudes among medical and nursing students. Aust NZ J Psych 1999;33: 260-266.

16. Sanchez NF, Rabatin J, Sanchez JP, Hubbard S, Kalet A: Medical students' ability to care for lesbian, gay, bisexual, and transgendered patients. Fam Med 2006;38:21-27.

17. Thomas JL, Scott LK, Brooks CM: Attitude change in a human sexuality course that de-emphasizes small group activities. Med Educ 1980;14(4):254-258.

18. Chng CL, Moore A: Can attitudes of college students towards AIDS and homosexuality be changed in six weeks? Health Val 1991;15:41-9.

19. Green S, Dixon P, Gold-Neil V: The effects of a gay/lesbian panel discussion on college student attitudes toward gay men, lesbians, and persons with AIDS. J Sex Educ Therap 1993;47-63.

20. Black B, Oles T, Moore L: Homophobia among students in social work programs. JBSW1996;2:23-41.

21. Morrison MA, Morrison TG: Development and Validation of a Scale Measuring Modern Prejudice Toward Gay Men and Lesbian Women. J Homosex 2011;43(2):15-37.

22. Norton AT, Herek GM: Heterosexuals' attitudes toward transgender people: findings from a national probability sample of U.S. adults. Sex Roles 2013;68(11):738-53.

23. Beagan BL., Fredericks E, Goldberg L: Nurses' work with LGBTQ patients: "They're just like everybody else, so what's the difference"? Can J Nurs Res 2012;44(3):44-63.

24. Banwari G, Mistry K, Soni A, Parikh N, Gandhi H: Medical students and interns' knowledge about and attitude towards homosexuality. J Postgr Med 2015;61(2):95-100.

25. Fisher AD, Castellini G, Ristori J, et al: Who has the worst attitudes toward sexual minorities? Comparison of transphobia and homophobia levels in gender dysphoric individuals, the general population and health care providers. $J$ Endocr Invest 2017;40(3):263-273.

26. Greene MZ, France K, Kreider EF, et al: Comparing medical, dental, and nursing students' preparedness to address lesbian, gay, bisexual, transgender, and queer health. PLoS One 208;13(9):e0204104.

27. Ali N, Fleisher W, Erickson J: Psychiatrists' and psychiatry residents' attitudes toward transgender people. Acad Psych 2015;40(2):268-73.

28. Klotzbaugh R, Spencer G: Magnet nurse administrator attitudes and opportunities: Toward improving lesbian, gay, bisexual, or transgender-specific healthcare. J Nurs Admin 2014;44(9):481-486.

29. Wilson CK, West L, Stepleman L, et al: Attitudes toward LGBT patients among students in the health professions: Influence of demographics and discipline. LGBT Health 2014;1:204-211.

30. Kissinger DB, Lee SM, Twitt L, Kisner H. Impact of family environment on future mental health professionals' attitudes toward lesbians and gay men. $J$ Homosex 2009;56(7): 894-920.

31. Swank E, Raiz L: Explaining comfort with homosexuality among social work students: The impact of demographic, contextual, and attitudinal factors. J Soc Work Educ 2007;43(2):257-79.

32. Wilton T, Kaufman T: Lesbian mothers' experiences of maternity care in the UK. Midwifery 2001;16(3):203-11.

33. Pratt-Chapman ML, Phillips S. Health Professional Student Preparedness to Care for Sexual and Gender Minorities: Efficacy of an Elective Learning Intervention. J Interpr Care 2019 [Epub ahead of print].

34. Crisp C. The Gay Affirmative Practice scale (GAP): A new measure for assessing cultural competence with gay and lesbian clients. Soc Work, 2006;51(2):115-126.

35. Dillman DA. Mail and internet surveys: The tailored design method (2nd ed.). New York: John Wiley \& Sons, 2000. 
36. Schim SM, Doorenbox AZ, Miller J, Benkert R. Development of a Cultural Competence assessment instrument. J Nurs Meas 2003;11(1):29-40.

37. Cheema JR. Some general guidelines for choosing missing data handling methods in educational research. J Mod App/ Stat Methods 2014;13(2):53-75.

38. Cohen J. Statistical power analysis for the behavioral sciences, 2nd ed. Hillsdale, NJ: Erlbaum, 1988.

39. Maxwell SE, Delaney HD: Designing experiments and analyzing data: A model comparison perspective, $2^{\text {nd }}$ ed. Mahwah, $\mathrm{NJ}$ : Earlbaum, 2004.

40. Kelley K, Maxwell SE. Multiple Regression. In G.R. Hancock, L.M. \& Stapleton, R.O. Mueller (Eds.) The Reviewer's Guide to Quantitative Methods in the Social Sciences, 1st ed. New York: Routledge. 2010.

41. Friston K: Ten ironic rules for non-statistical reviewers. Neurolmage 2012;61:1300-1310.

\section{Tables}


Table 1

Sample Characteristics $(n=48)$

\begin{tabular}{|c|c|c|}
\hline Variable & Level & Statistic \\
\hline Role, n (\%) & $\begin{array}{l}\text { Medical student (preclinical) } \\
\text { Medical student (clinical) } \\
\text { Other health graduate student }\end{array}$ & $\begin{array}{l}7(14.6) \\
25(52.1) \\
16(33.3)\end{array}$ \\
\hline Age, M (SD) & & $26(4.1)$ \\
\hline Race+, n (\%) & $\begin{array}{l}\text { Asian } \\
\text { Black } \\
\text { Hispanic } \\
\text { White } \\
\text { Other } \\
\text { System missing or Refused }\end{array}$ & $\begin{array}{l}13(27.1) \\
1(2.1) \\
4(8.3) \\
31(64.6) \\
1(2.1) \\
1(2.1)\end{array}$ \\
\hline Sex-assigned-at-birth, n (\%) & $\begin{array}{l}\text { Female } \\
\text { Male }\end{array}$ & $\begin{array}{l}33(68.8) \\
15(31.3)\end{array}$ \\
\hline Gender identity & $\begin{array}{l}\text { Female } \\
\text { Male } \\
\text { Transgender/ Genderqueer }\end{array}$ & $\begin{array}{l}33(68.8) \\
15(31.3) \\
0(0)\end{array}$ \\
\hline Sexual orientation, n (\%) & $\begin{array}{l}\text { Straight } \\
\text { Bisexual } \\
\text { Lesbian or gay } \\
\text { Other (e.g. asexual, queer, pansexual) }\end{array}$ & $\begin{array}{l}32(66.7) \\
6(12.5) \\
8(16.7) \\
2(4.2)\end{array}$ \\
\hline SGM affiliation & $\begin{array}{l}\text { Self-identify as SGM } \\
\text { Family member who is SGM } \\
\text { Friend who is SGM } \\
\text { Acquaintance who is SGM } \\
\text { Do not know anyone SGM }\end{array}$ & $\begin{array}{l}14(29.2) \\
6(12.5) \\
22(45.8) \\
6(12.5) \\
0(0)\end{array}$ \\
\hline Political affiliation, n (\%) & $\begin{array}{l}\text { Very liberal } \\
\text { Liberal } \\
\text { Neither liberal or conservative } \\
\text { Somewhat conservative } \\
\text { Very conservative } \\
\text { Apolitical }\end{array}$ & $\begin{array}{l}21(43.8) \\
22(45.8) \\
0(0) \\
4(8.3) \\
1(2.1) \\
0(0)\end{array}$ \\
\hline Religion, n (\%) & $\begin{array}{l}\text { Agnostic } \\
\text { Atheist } \\
\text { Christian: Catholic } \\
\text { Christian: Protestant } \\
\text { Hindu } \\
\text { Jewish } \\
\text { Muslim } \\
\text { Other } \\
\text { Prefer not to answer } \\
\text { System missing }\end{array}$ & $\begin{array}{l}11(22.9) \\
5(10.4) \\
11(22.9) \\
8(16.7) \\
3(6.3) \\
6(12.5) \\
1(2.1) \\
5(12.5) \\
1(2.1) \\
5(10.4)\end{array}$ \\
\hline Spirituality, n (\%) & $\begin{array}{l}\text { Not at all spiritual } \\
\text { Slightly spiritual } \\
\text { Somewhat spiritual } \\
\text { Very spiritual }\end{array}$ & $\begin{array}{l}6(12.5) \\
15(31.3) \\
20(41.7) \\
7(14.6)\end{array}$ \\
\hline Religiosity, n (\%) & $\begin{array}{l}\text { Not at all religious } \\
\text { Slightly religious } \\
\text { Somewhat religious } \\
\text { Very religious }\end{array}$ & $\begin{array}{l}16(33.3 .) \\
16(33.3) \\
12(25.0) \\
4(8.3)\end{array}$ \\
\hline
\end{tabular}

+Categories were not mutually exclusive 
Table 2

Model Comparisons: LGBT-DOCSS Basic Knowledge $(n=48)$

\begin{tabular}{|c|c|c|c|c|c|c|c|c|c|c|c|c|}
\hline & \multicolumn{6}{|c|}{ Individual Predictors } & \multicolumn{6}{|c|}{ Model Statistics } \\
\hline & $b$ & SE b & B & $\mathrm{t}$ & $\mathrm{p}$ & $s r^{2}$ & $\mathrm{R}$ & $\mathrm{R}^{2}$ & dfreg & dfres & $\mathrm{F}$ & $\mathrm{p}$ \\
\hline $\begin{array}{l}\text { Full Model : } 8 \\
\text { IV's }\end{array}$ & & & & & & & 0.451 & 0.204 & 8 & 39 & 1.247 & 0.299 \\
\hline $\begin{array}{l}\text { Sexual } \\
\text { orientation }(0= \\
\text { LGB, } 1 \text { = Straight })\end{array}$ & 0.791 & 0.817 & 0.164 & 0.968 & 0.339 & 0.019 & & & & & & \\
\hline $\begin{array}{l}\text { Sex-assigned-at- } \\
\text { birth }(0=F, 1= \\
M)\end{array}$ & 0.539 & 0.801 & 0.110 & 0.673 & 0.505 & 0.009 & & & & & & \\
\hline $\begin{array}{l}\text { Political } \\
\text { affiliation (0 = } \\
\text { Liberal, } 1=\text { Not } \\
\text { liberal) }\end{array}$ & -0.658 & 1.152 & -0.088 & -0.571 & 0.571 & 0.007 & & & & & & \\
\hline $\begin{array}{l}\text { Religiosity ( } 0= \\
\text { Not religious, } 1= \\
\text { Religious) }\end{array}$ & -1.441 & 0.806 & -0.298 & -1.788 & 0.082 & $0.065 \infty$ & & & & & & \\
\hline $\begin{array}{l}\text { Spirituality }(0= \\
\text { Not spiritual, } 1= \\
\text { Spiritual) }\end{array}$ & 0.147 & 0.766 & 0.032 & 0.192 & 0.849 & 0.001 & & & & & & \\
\hline $\begin{array}{l}\text { SGM affiliation } \\
(0=\text { SGM } \\
\text { affiliation, } 1=\text { No } \\
\text { affiliation })\end{array}$ & -1.965 & 1.154 & -0.285 & -1.703 & 0.097 & $0.059 \infty$ & & & & & & \\
\hline $\begin{array}{l}\text { Number of } \\
\text { patients } \\
\text { (continuous) }\end{array}$ & -0.020 & 0.018 & -0.201 & -1.150 & 0.257 & $0.027 \infty$ & & & & & & \\
\hline $\begin{array}{l}\text { Number of SGM } \\
\text { training hours } \\
\text { (continuous) }\end{array}$ & 0.011 & 0.011 & 0.161 & -1.150 & 0.359 & 0.018 & & & & & & \\
\hline $\begin{array}{l}\text { Reduced Model: } \\
3 \text { IV's }\end{array}$ & & & & & & & 0.402 & 0.161 & 3 & 44 & 2.822 & 0.050 * \\
\hline $\begin{array}{l}\text { Religiosity ( } 0= \\
\text { Not religious, } 1= \\
\text { Religious) }\end{array}$ & -1.393 & 0.669 & -0.289 & -2.082 & $0.043^{*}$ & $0.083 \infty$ & & & & & & \\
\hline $\begin{array}{l}\text { SGM affiliation } \\
(0=\text { SGM } \\
\text { affiliation, } 1=\text { No } \\
\text { affiliation) }\end{array}$ & -1.872 & 0.973 & -0.272 & -1.923 & 0.061 & $0.071 \infty$ & & & & & & \\
\hline $\begin{array}{l}\text { Number of } \\
\text { patients } \\
\text { (continuous) }\end{array}$ & -0.011 & 0.014 & -0.106 & -0.748 & 0.458 & 0.011 & & & & & & \\
\hline
\end{tabular}

* indicates $p<.05 ; \infty$ indicates $>2 \%$ unique variance explained 
Table 3

Model Comparisons: LGBT-DOCSS Attitudinal Awareness $(n=48)$

\begin{tabular}{|c|c|c|c|c|c|c|c|c|c|c|c|c|}
\hline & \multicolumn{6}{|c|}{ Individual Predictors } & \multicolumn{6}{|c|}{ Model Statistics } \\
\hline & $\mathrm{b}$ & SE b & B & $\mathrm{t}$ & $\mathrm{p}$ & $s r^{2}$ & $\mathrm{R}$ & $\mathrm{R}^{2}$ & dfreg & dfres & $\mathrm{F}$ & $\mathrm{p}$ \\
\hline $\begin{array}{l}\text { Full Model : } \\
8 \mathrm{IV} \text { 's }\end{array}$ & & & & & & & 0.725 & 0.526 & 8 & 39 & 5.404 & $<.001^{\star *}$ \\
\hline $\begin{array}{l}\text { Sexual } \\
\text { orientation } \\
(0=L G B, 1= \\
\text { Straight })\end{array}$ & -1.043 & 1.411 & -0.097 & -0.739 & 0.464 & 0.007 & & & & & & \\
\hline $\begin{array}{l}\text { Sex- } \\
\text { assigned-at- } \\
\text { birth }(0=\mathrm{F} \\
1=\mathrm{M})\end{array}$ & -0.187 & 1.383 & -0.017 & -0.135 & 0.893 & 0.000 & & & & & & \\
\hline $\begin{array}{l}\text { Political } \\
\text { affiliation (0 } \\
=\text { Liberal, } 1 \\
=\text { Not liberal) }\end{array}$ & -10.845 & 1.990 & -0.650 & -5.450 & $<.001 * *$ & $0.361 \infty$ & & & & & & \\
\hline $\begin{array}{l}\text { Religiosity } \\
(0=\text { Not } \\
\text { religious, } 1 \\
=\text { Religious })\end{array}$ & -0.437 & 1.392 & -0.040 & -0.314 & 0.755 & 0.001 & & & & & & \\
\hline $\begin{array}{l}\text { Spirituality } \\
(0=\text { Not } \\
\text { spiritual, } 1= \\
\text { Spiritual })\end{array}$ & -0.233 & 1.322 & -0.023 & -0.176 & 0.861 & $<0.001$ & & & & & & \\
\hline $\begin{array}{l}\text { SGM } \\
\text { affiliation (0 } \\
=\text { SGM } \\
\text { affiliation, } 1 \\
=\text { No } \\
\text { affiliation) }\end{array}$ & -1.076 & 1.993 & -0.070 & -0.540 & 0.592 & 0.004 & & & & & & \\
\hline $\begin{array}{l}\text { Number of } \\
\text { patients } \\
\text { (continuous) }\end{array}$ & -0.025 & 0.030 & -0.110 & -0.814 & 0.421 & 0.008 & & & & & & \\
\hline $\begin{array}{l}\text { Number of } \\
\text { SGM } \\
\text { training } \\
\text { hours } \\
\text { (continuous) }\end{array}$ & -0.020 & 0.020 & -0.136 & -1.012 & 0.318 & 0.012 & & & & & & \\
\hline $\begin{array}{l}\text { Reduced } \\
\text { Model : } 1 \mathrm{IV}\end{array}$ & & & & & & & 0.682 & 0.465 & 1 & 46 & 40.007 & $<.001^{\star *}$ \\
\hline $\begin{array}{l}\text { Political } \\
\text { affiliation (0 } \\
=\text { Liberal, } 1 \\
=\text { Not liberal) }\end{array}$ & -11.372 & 1.798 & -0.682 & -6.325 & $<.001 * *$ & $0.465 \infty$ & & & & & & \\
\hline
\end{tabular}

* indicates $p<.05$; ** indicates $p<.001 ; \infty$ indicates $>2 \%$ unique variance explained 
Table 4

Model Comparisons: LGBT-DOCSS Clinical Preparedness $(n=48)$

\begin{tabular}{|c|c|c|c|c|c|c|c|c|c|c|c|c|}
\hline & \multicolumn{6}{|c|}{ Individual Predictors } & \multicolumn{6}{|c|}{ Model Statistics } \\
\hline & $\mathrm{b}$ & SE b & B & $\mathrm{t}$ & $\mathrm{p}$ & $\mathrm{sr}^{2}$ & $\mathrm{R}$ & $\mathrm{R}^{2}$ & dfreg & dfres & $\mathrm{F}$ & $\mathrm{p}$ \\
\hline Full Model : 8 IV's & & & & & & & 0.354 & 0.125 & 8 & 39 & 0.698 & 0.691 \\
\hline $\begin{array}{l}\text { Sexual orientation } \\
(0=L G B, 1= \\
\text { Straight })\end{array}$ & -0.122 & 1.996 & -0.011 & -0.061 & 0.952 & 0.000 & & & & & & \\
\hline $\begin{array}{l}\text { Sex-assigned-at- } \\
\text { birth }(0=F, 1=M)\end{array}$ & -0.845 & 1.956 & -0.074 & -0.432 & 0.668 & 0.004 & & & & & & \\
\hline $\begin{array}{l}\text { Political affiliation } \\
(0=\text { Liberal, } 1=\text { Not } \\
\text { liberal })\end{array}$ & -1.424 & 2.816 & -0.082 & -0.506 & 0.616 & 0.006 & & & & & & \\
\hline $\begin{array}{l}\text { Religiosity }(0=\text { Not } \\
\text { religious, } 1= \\
\text { Religious) }\end{array}$ & -2.351 & 1.970 & -0.209 & -1.194 & 0.240 & $0.032 \infty$ & & & & & & \\
\hline $\begin{array}{l}\text { Spirituality ( } 0=\text { Not } \\
\text { spiritual, } 1= \\
\text { Spiritual) }\end{array}$ & 1.944 & 1.871 & 0.182 & 1.039 & 0.305 & $0.024 \infty$ & & & & & & \\
\hline $\begin{array}{l}\text { SGM affiliation (0 } \\
=\text { SGM affiliation, } \\
1 \text { = No affiliation) }\end{array}$ & -0.719 & 2.820 & -0.045 & -0.255 & 0.800 & 0.001 & & & & & & \\
\hline $\begin{array}{l}\text { Number of patients } \\
\text { (continuous) }\end{array}$ & -0.012 & 0.043 & -0.050 & -0.274 & 0.785 & 0.002 & & & & & & \\
\hline $\begin{array}{l}\text { Number of SGM } \\
\text { training hours } \\
\text { (continuous) }\end{array}$ & 0.036 & 0.028 & 0.237 & 1.303 & 0.200 & $0.038 \infty$ & & & & & & \\
\hline $\begin{array}{l}\text { Reduced Model : } 3 \\
\text { IV's }\end{array}$ & & & & & & & 0.328 & 0.108 & 3 & 44 & 1.768 & 0.167 \\
\hline $\begin{array}{l}\text { Religiosity ( } 0=\text { Not } \\
\text { religious, } 1= \\
\text { Religious) }\end{array}$ & -2.486 & 1.792 & -0.221 & -1.388 & 0.172 & $0.039 \infty$ & & & & & & \\
\hline $\begin{array}{l}\text { Spirituality ( } 0=\text { Not } \\
\text { spiritual, } 1= \\
\text { Spiritual) }\end{array}$ & 2.040 & 1.720 & 0.191 & 1.186 & 0.242 & $0.029 \infty$ & & & & & & \\
\hline $\begin{array}{l}\text { Number of SGM } \\
\text { training hours } \\
\text { (continuous) }\end{array}$ & 0.035 & 0.022 & 0.226 & 1.566 & 0.125 & $0.050 \infty$ & & & & & & \\
\hline
\end{tabular}

* indicates $p<.05 ; \infty$ indicates $>2 \%$ unique variance explained 
Table 5

Model Comparisons: GAPS Beliefs $(n=48)$

\begin{tabular}{|c|c|c|c|c|c|c|c|c|c|c|c|c|}
\hline & \multicolumn{6}{|c|}{ Individual Predictors } & \multicolumn{6}{|c|}{ Model Statistics } \\
\hline & $b$ & SE b & B & $\mathrm{t}$ & $\mathrm{p}$ & $s r^{2}$ & $\mathrm{R}$ & $R^{2}$ & dfreg & dfres & $\mathrm{F}$ & $\mathrm{p}$ \\
\hline $\begin{array}{l}\text { Full Model: } \\
8 \text { IV's }\end{array}$ & & & & & & & 0.706 & 0.498 & 8 & 39 & 4.839 & $<.001 * *$ \\
\hline $\begin{array}{l}\text { Sexual } \\
\text { orientation } \\
(0=L G B, 1= \\
\text { Straight })\end{array}$ & -1.514 & 2.161 & -0.094 & -0.700 & 0.488 & 0.006 & & & & & & \\
\hline $\begin{array}{l}\text { Sex- } \\
\text { assigned-at- } \\
\text { birth }(0=\mathrm{F} \\
1=\mathrm{M})\end{array}$ & -1.204 & 2.118 & -0.074 & -0.568 & 0.573 & 0.004 & & & & & & \\
\hline $\begin{array}{l}\text { Political } \\
\text { affiliation (0 } \\
=\text { Liberal, } 1 \\
\text { = Not liberal) }\end{array}$ & -12.058 & 3.049 & -0.485 & -3.954 & $<.001^{\star *}$ & $0.201 \infty$ & & & & & & \\
\hline $\begin{array}{l}\text { Religiosity } \\
(0=\text { Not } \\
\text { religious, } 1 \\
=\text { Religious })\end{array}$ & -1.595 & 2.133 & -0.099 & -0.747 & 0.459 & 0.007 & & & & & & \\
\hline $\begin{array}{l}\text { Spirituality } \\
(0=\text { Not } \\
\text { spiritual, } 1= \\
\text { Spiritual) }\end{array}$ & 0.418 & 2.026 & 0.027 & 0.206 & 0.838 & 0.001 & & & & & & \\
\hline $\begin{array}{l}\text { SGM } \\
\text { affiliation (0 } \\
=\text { SGM } \\
\text { affiliation, } 1 \\
=\text { No } \\
\text { affiliation) }\end{array}$ & -7.433 & 3.054 & -0.324 & -2.434 & $0.020^{\star}$ & $0.076 \infty$ & & & & & & \\
\hline $\begin{array}{l}\text { Number of } \\
\text { patients } \\
\text { (continuous) }\end{array}$ & $<0.001$ & 0.047 & 0.000 & 0.000 & 1.000 & $<0.001$ & & & & & & \\
\hline $\begin{array}{l}\text { Number of } \\
\text { SGM } \\
\text { training } \\
\text { hours } \\
\text { (continuous) }\end{array}$ & -0.007 & 0.030 & -0.034 & -0.247 & 0.806 & 0.001 & & & & & & \\
\hline $\begin{array}{l}\text { Reduced } \\
\text { Model : } 2 \\
\text { IV's }\end{array}$ & & & & & & & 0.693 & 0.480 & & & 20.786 & $\dot{0.001 * *}$ \\
\hline $\begin{array}{l}\text { Political } \\
\text { affiliation (0 } \\
=\text { Liberal, } 1 \\
=\text { Not liberal) }\end{array}$ & -12.561 & 2.784 & -0.506 & -4.512 & $<.001$ ** & $0.235 \infty$ & & & & & & \\
\hline $\begin{array}{l}\text { SGM } \\
\text { affiliation (0 } \\
=\text { SGM } \\
\text { affiliation, } 1 \\
=\text { No } \\
\text { affiliation) }\end{array}$ & -8.067 & 2.571 & -0.352 & -3.137 & $0.003^{\star}$ & $0.114 \infty$ & & & & & & \\
\hline
\end{tabular}

* indicates $p<.05$; ** indicates $p<.001 ; \infty$ indicates $>2 \%$ unique variance explained 
Table 6

Model Comparisons: GAPS Behaviors $(n=48)$

\begin{tabular}{|c|c|c|c|c|c|c|c|c|c|c|c|c|}
\hline & \multicolumn{6}{|c|}{ Individual Predictors } & \multicolumn{6}{|c|}{ Model Statistics } \\
\hline & b & SE b & $B$ & $\mathrm{t}$ & $\mathrm{p}$ & $\mathrm{sr}^{2}$ & $\mathrm{R}$ & $R^{2}$ & dfreg & dfres & $\mathrm{F}$ & $\mathrm{p}$ \\
\hline $\begin{array}{l}\text { Full Model : } \\
8 \mathrm{IV} \text { 's }\end{array}$ & & & & & & & 0.73 & 0.533 & 8 & 39 & 5.571 & $\begin{array}{l}< \\
0.001^{\star *}\end{array}$ \\
\hline $\begin{array}{l}\text { Sexual } \\
\text { orientation } \\
(0=L G B, 1= \\
\text { Straight })\end{array}$ & -4.789 & 3.249 & -0.191 & -1.474 & 0.149 & 0.026 & & & & & & \\
\hline $\begin{array}{l}\text { Sex- } \\
\text { assigned-at- } \\
\text { birth }(0=\mathrm{F} \\
1=\mathrm{M})\end{array}$ & -0.106 & 3.185 & -0.004 & -0.033 & 0.974 & 0.000 & & & & & & \\
\hline $\begin{array}{l}\text { Political } \\
\text { affiliation (0 } \\
=\text { Liberal, } 1 \\
=\text { Not liberal) }\end{array}$ & -14.587 & 4.584 & -0.377 & -3.182 & $0.003^{*}$ & $0.121 \infty$ & & & & & & \\
\hline $\begin{array}{l}\text { Religiosity } \\
(0=\text { Not } \\
\text { religious, } 1 \\
=\text { Religious })\end{array}$ & -3.534 & 3.207 & -0.141 & -1.102 & 0.277 & 0.015 & & & & & & \\
\hline $\begin{array}{l}\text { Spirituality } \\
(0=\text { Not } \\
\text { spiritual, } 1= \\
\text { Spiritual })\end{array}$ & 8.096 & 3.046 & 0.34 & 2.658 & $0.011^{*}$ & $0.085 \infty$ & & & & & & \\
\hline $\begin{array}{l}\text { SGM } \\
\text { affiliation (0 } \\
=\text { SGM } \\
\text { affiliation, } 1 \\
=\text { No } \\
\text { affiliation) }\end{array}$ & -4.474 & 4.591 & -0.125 & -0.975 & 0.336 & 0.011 & & & & & & \\
\hline $\begin{array}{l}\text { Number of } \\
\text { patients } \\
\text { (continuous) }\end{array}$ & 0.005 & 0.070 & 0.009 & 0.069 & 0.945 & 0.000 & & & & & & \\
\hline $\begin{array}{l}\text { Number of } \\
\text { SGM } \\
\text { training } \\
\text { hours } \\
\text { (continuous) }\end{array}$ & 0.120 & 0.045 & 0.350 & 2.633 & $0.012^{\star}$ & $0.083 \infty$ & & & & & & \\
\hline $\begin{array}{l}\text { Reduced } \\
\text { Model : } 4 \\
\text { IV's }\end{array}$ & & & & & & & 0.712 & 0.507 & & & 11.036 & $\begin{array}{l}<.001 * * \\
0.00\end{array}$ \\
\hline $\begin{array}{l}\text { Sexual } \\
\text { orientation } \\
(0=L G B, 1= \\
\text { Straight })\end{array}$ & -6.180 & 2.704 & -0.246 & -2.286 & $0.027^{\star}$ & $0.060 \infty$ & & & & & & \\
\hline $\begin{array}{l}\text { Political } \\
\text { affiliation (0 } \\
=\text { Liberal, } 1 \\
=\text { Not liberal) }\end{array}$ & -16.603 & 4.227 & -0.429 & -3.928 & $<.001^{\star *}$ & $0.177 \infty$ & & & & & & \\
\hline $\begin{array}{l}\text { Spirituality } \\
(0=\text { Not } \\
\text { spiritual, } 1= \\
\text { Spiritual) }\end{array}$ & 7.238 & 2.619 & 0.304 & 2.763 & $0.008^{*}$ & $0.088 \infty$ & & & & & & \\
\hline
\end{tabular}




\begin{tabular}{|c|c|c|c|c|c|c|}
\hline & Indivic & Predict & & \multicolumn{3}{|c|}{ Model Statistics } \\
\hline $\begin{array}{l}\text { Number of } \\
\text { SGM } \\
\text { training } \\
\text { hours } \\
\text { (continuous) }\end{array}$ & 0.130 & 0.037 & 0.381 & 3.510 & $0.001 *$ & $0.141 \infty$ \\
\hline
\end{tabular}

* indicates $p<.05 ; \infty$ indicates $>2 \%$ unique variance explained 